\title{
Physical Proximity and Awareness of Financial Service Access Strategy on Farmers Economic Empowerment in Kenya: A Case of Small Scale Agricultural Tea Farmers in Kisii County
}

\author{
Thomas Ombui Nyakweba, Prof. George Gongera, Dr. Irine Koech Asianga
}

\begin{abstract}
The focus of this research was to identify physical access, that is, presence of bank branches that is often considered the most important source of access to finance in developing countries and awareness. Despite the notion of branchless banking and availability of ATM machines, yet easy access to a normal bank branch staffed with people is still very important in the less developed areas. Access to bank branches, develops the habit of banking which leads to increased savings and investment, improved efficiency of allocation of capital, and increase the ability of monetary authorities to stabilize the economy while the amount of saving depends partly on how widespread these facilities are. Stratified and random sampling was used and the sample size was 398 of the respondents. Questionnaires and observations were used to collect data. Data analysis was done by use of SPSS. Objective of the study was to identify physical proximity and awareness of financial service access strategy on economic empowerment among Small Scale Tea Farmers in Kisii county-Kenya. Findings revealed a statistically significant weak positive relationship between physical proximity on access to financial services and economic empowerment $(r=0.428, p<0.05)$. It was concluded that, there is inadequate infrastructure development in the rural areas thus affecting financial accessibility among tea farmers. It was recommended that this study be carried on a broader scale in Kenya.
\end{abstract}

Index Terms - Financial Access, Physical Proximity, Awareness, Strategy, Economic Empowerment, Tea Farmers.

\section{INTRODUCTION}

Tea farming has been practiced in Kisii County for more than five decades. This cash crop is more depended on by many farmers in the county. Currently, more than 77035 growers are engaged in tea farming, KTDA region 6 (2018). Despite the fact that they receive monthly and yearly payments, majority of these farmers are living in deplorable conditions due to limited financial services access to boost their livelihoods. It is not clear whether it is due to limited financial institutions around them or awareness of funding opportunities to access financial services for their economic empowerment.

Thomas Ombui Nyakweba, Kabarak University, School Of Busines and Economics, Kenya

Prof. George Gongera, Kabarak University, School Of Business and Economics , Kenya

Dr. Irine Koech Asianga, Kabarak University, School Of Business and Economics, Kenya.
In India the "broad approach to financial inclusion aims at 'connecting people' with the banking system and not just credit dispensation; giving people access to payments system and portray financial inclusion as a viable business model and opportunity" Reserve Bank of India, (2008). Access could include access to various financial products and services, bank accounts, bank credit, savings products, remittances and payment services, insurance services, home mortgage and financial advisory services.

A study by the Partnerships for Financial Inclusion in Latin America and the Caribbean: A Catalyst for Inclusive Growth (2014) pointed out that, in order to access financial services, people living in rural areas require the possibility of finding institutions near their home, as transaction costs are high, due to lack of infrastructure, the distance and/or access to transportation. The latter also affects the supply of those financial services. This situation hampers the chances people have of accessing services, products and financial channels. It also generates misinformation regarding how the formal financial system works, and about products, usages, rights and duties of clients, and financial services.

\section{A. Significance of the study}

The study focused on financial access strategies that were to empower tea farmers economically to raise their standard of living by accessing financial services from financial providers. It was to provide a clear distinction between standard of living and quality of life variables in measuring the economic situation of tea growers. This was to provide better understanding and clarity to the implication of the findings for comparison by future studies; and its outcome will be useful as reference materials for government, development agencies and other publics in the provision of financial services to tea farmers. The research was expected to deepen the understanding of the challenges and opportunities of communities living and working in the tea sector so that ways were to be found to address the issues in the short and long term basis.

\section{LITERATURE REVIEW}

Physical access, that is, presence of bank branches is often considered the most important source of access to finance in developing countries. Despite the notion of 


\section{Physical Proximity and Awareness of Financial Service Access Strategy on Farmers Economic Empowerment in Kenya: A Case of Small Scale Agricultural Tea Farmers in Kisii County}

branchless banking and availability of ATM machines, yet easy access to a normal bank branch is very important in the less developed areas. Access to bank branches, as (Porter,1966) pointed out, develops the habit of banking which leads to increased savings and investment, improve the efficiency of allocation of capital, and increase the ability of monetary authorities to stabilize the economy. Lack of bank branches in the local areas can prevent the unbanked from gaining access to formal financial sector services. The World Bank (2008) report deemed that physical access is one of the major constraints to financial access. The bank highlighted that there are different opportunities that financial institutions provide to their clientele as a way of tackling this issue. Some institutions allow clients to access services over the phone or via the internet; others require them to visit a branch or automated teller machine. The World Bank proposed that ideal measure would indicate the average distance from household to branch (or ATM), the density of branches per square kilometer or per capita, providing an initial, albeit crude indicator.

Physical distance of farm households from formal lending institutions is one of the factors that influence access to formal credit. Burgess and Pande (2005) has cited by (Haniffa, R. and Hudaib, M., 2006) found that state-led expansion of rural bank branches in India has helped reduce poverty. Specifically, the authors found robust evidence that opening bank branches in rural unbanked locations in India was associated with reduction in rural poverty rates in those areas. Technological innovations, such as prepaid cards to distribute loan payments and mobile phone plans to make loan payments and transfer cash, make it easier for women to gain access to capital by reducing the need for women to travel long distances, allowing them to sidestep social constraints that restrict the areas women can visit or the people with whom they can interact (Duncombe, 2009). Banking expansion in Kenya has coincided with the rise of Equity Bank, a pioneering for profit bank that devised a banking service strategy targeting low income clients and traditionally under-served territories. However, people are not adequately empowered since most rural farmers hardly have Bank accounts.

In Ugandan government announced in January 2009 that its coffee exports dropped both in volume ( 8 per cent) and value (23 per cent or USD 10 million) due to logistical problems and limited supply of containers compared with the same month in 2008, (Neven et al., 2009).

In Kenya - Kisii underdeveloped rural roads and other key physical infrastructure have led to high transport costs for agricultural products to the market as well as of farm inputs and electricity in rural areas is expensive and often not available reducing farmers' competitiveness. Questions to ask are: how do farmers access their funds for economic sustainability when tea rots at the buying centers before being delivered to the factories because of transportation and storage facilities? How does this crop (tea) benefit the grower as it goes to waste before it can be weight due to lack of road net work?
World Bank

agriculture-related infrastructure, such as rural roads, port facilities, loading terminals, is needed in most of the poorest countries. Currently transportation costs are often too high; particularly for landlocked areas where moving food in and out becomes almost impossible because of poor logistics and high costs.

In Kisii County, poor infrastructure, unreliable electricity, high costs of fuel and packaging materials further increase production costs (KTDA, 2015). The factories have been the hardest hit by the ban on procurement of wood fuel from the forest. This is because they rely on wood fuel to cure the tea. Since the ban was affected three years ago the factories have been forced to procure fuel from the farms where trees are rare and therefore sold at exorbitant prices. Besides storage facilities and collection centers are won out. From the literature above it can be seen clearly how farmers financial service access strategies are required to empower themselves economically.

The adequacy and availability of information in the financial market is critical for both SMEs and financial providers. In order for SMEs tea farmers to identify potential supplier of financial services, they require enough information. Othieno (2010) argues that financial institutions require information to enable them to evaluate the potential risks associated with the SMEs that apply for bank financing and also to access the location where the same SMEs will be operating and its market segments. Information tries to determine awareness of funding opportunities by SMEs. In addition, information asymmetry is that relevant information is not available and known to all players in the financial market (Agostino, 2008). Bazibu (2005) observed that Information asymmetries are actually concerned with the two players in the financial market, the borrowers who know more about their business cases and the bankers who may not know more about it on one hand. On the other hand, it entails the lack of timely, accurate, quality, quantity, and completes information regarding the ability of the applicants to repay back the loan and to access financial products from the banking institutions.

Agostino further asserted that the failure of the current African market is because of the number of the current agricultural credit problems associated with the imperfection of the information in the risk presences and the failures of the market, that mostly occur due to the fact that it is costly to screen credit applicants. Small-scale tea farmers have a limitation to access loans from financial providers due to security requirements. A study by Kumar (2011) on the analysis of farmer's perception and awareness towards crop insurance as tool for risk management in Tamil Nadu-India, revealed that most farmers $(65 \%)$ are aware of risk mitigation measures of the government, however only half of them were found aware of crop insurance scheme products. This casts shadows on these insurance schemes; whether it gives access to financial service for farmers empowerment or not, or they are just aware?

In a related study by Babara revealed that, farmers do not have in-depth awareness about crop insurance scheme. The financial viability of National Agricultural Insurance Scheme 
(NAIS) is very poor as it assumes loss ratio greater than profits gained by tea farmers in Kisii. Lack of sufficient market information predisposes small enterprises to a great challenge. Baloyi (2010) made a similar conclusion that access to market alone is not good enough but market information is also necessary. Market information include; product prices at national level, quality requirements, the best places and time to sell their products and information about their competitors and potential customers.

Baloyi further, observed that one of the greatest impediments of development of rural farmers is lack of markets in rural areas. He contends that most small holders are located in rural areas where there are no formal markets. The farmers are compelled to market their produce to local communities in their areas, sometimes at a lower price or transport their produce to towns at a higher cost. According to Baloyi, this further leads to low bargaining power since they have poor access to market information and limited access to financial markets, which hinders them from selling their produce at competitive prices. He recommended that in order to ensure market participation by small holder farmers it requires that they gain access to reliable and high quality farmer support services such as production inputs, on farm infrastructure, training and extension services.

Kyale (2013) observed that microfinance institutions have managed to register MFIs in farm associations and updated their data bases as a way to facilitate marketing. $\mathrm{He}$ further posited that those who were beneficiaries of market facilitation by MFI said that it boosted their income from their farms. Kyale recommended that intensified use and facilitation of ICT would go a long way in helping the MFIs to boost their income. Therefore, this study seeks to assess awareness of the market as an economic financial access factor for tea farmers economic empowerment in kisii county- kenya.

According to (Nam and Ellinger, 2008), the advent of communication technologies have helped to reduce transactions costs associated with banking activities. However, (Porteous,2006) observed that, a number of emerging mobile financial tools have been developed including the M-Pesa in Kenya, MTN mobile Money in South Africa and privately operated mobile money transfers in Rwanda. An important realization, however, is that rural consumers are in themselves very diverse with differing needs and thus constituting varying marketing segments (Kaynak and Harcar, 2005).

The Technology, for instance, encapsulates many of the factors initially recognized to be critical in the adoption of agricultural innovations namely relative advantage, complexity, risk and compatibility (Tobbin, 2012; Zhao et al. 2008; Eriksson et al., 2008; Laforet and Li, 2005). Recent research on financial services in developed countries focused on the role of internet banking as an alternative for consumers (Berndt et al., 2010; Zhao et al., 2008, Nam and Ellinger, 2008, Gan et al, 2006, Kaynak and Harcar, 2005). Studies in developing countries including Ghana, Malaysia, South Africa, Indonesia, Kenya, Rwanda, Philippines is still grappling with the issues related to whether rural consumers could possibly accept to have bank accounts of their own and associated mobile technology (Saunders et al., 2007). Tustin (2010) poised that enhancing financial knowledge on products and services among the poor may be important in enhancing their ultimate choice of banking intermediary in South Africa. Tobbin (2012) explored the possibility of adopting mobile banking in rural Ghana and showed that perceived usefulness, ease of use and trust were essential factors underlying consumers' decisions.

\section{RESEARCH METHODOLOGY}

The research was expected to describe the variables in a situation of interest to the researcher. Thus this study is descriptive in nature. Descriptive study is appropriate because the nature of the problem was well known and the objective is clearly specified, Kothari (2004).In this study, the target population comprised of 77035 small scale tea farmers in Kisii County. Using Yamane (1967) formula, the researcher had a sample size of 398 respondents distributed as under:

Table 1: Distribution of respondents

\begin{tabular}{|c|c|c|c|c|}
\hline $\begin{array}{r}\text { Target Population } \\
\text { Category }\end{array}$ & Constituency & $\begin{array}{c}\text { Target } \\
\text { Population }\end{array}$ & $\begin{array}{l}\text { Sample } \\
\text { Size }\end{array}$ & $\begin{array}{l}\text { Selection } \\
\text { Method }\end{array}$ \\
\hline \multirow[t]{2}{*}{$\begin{array}{l}\text { Nyamache Factory } \\
\text { main } \\
\text { Nyamche } \\
\text { branch-Itumbe }\end{array}$} & \multirow[t]{2}{*}{ Bobasi } & 16454 & 85 & $\begin{array}{l}\text { Randomly } \\
\text { selected }\end{array}$ \\
\hline & & 12409 & 64 & $\begin{array}{l}\text { Randomly } \\
\text { selected }\end{array}$ \\
\hline \multirow{2}{*}{$\begin{array}{l}\text { Ogembo main } \\
\text { factory } \\
\text { Ogembo } \\
\text { branch-Eberege }\end{array}$} & \multirow{2}{*}{$\begin{array}{l}\text { MachogechacheMachogeborabu } \\
\text { South mugirango } \\
\text { Bonchari }\end{array}$} & 15854 & 81.9 & $\begin{array}{l}\text { Randomly } \\
\text { Selected }\end{array}$ \\
\hline & & 11805 & 60.99 & Randomly \\
\hline
\end{tabular}


Physical Proximity and Awareness of Financial Service Access Strategy on Farmers Economic Empowerment in Kenya: A Case of Small Scale Agricultural Tea Farmers in Kisii County

\begin{tabular}{|c|c|c|c|c|}
\hline & & & & selected \\
\hline \multirow{2}{*}{$\begin{array}{l}\text { Kiamokama main } \\
\text { factory } \\
\text { Branch-Rianyamwa } \\
\text { mu }\end{array}$} & \multirow[t]{2}{*}{$\begin{array}{l}\text { Nyaribarimasaba } \\
\text { Nyaribarichache }\end{array}$} & 12176 & 60.907 & $\begin{array}{l}\text { Randomly } \\
\text { selected }\end{array}$ \\
\hline & & 8337 & 43.07 & $\begin{array}{l}\text { Randomly } \\
\text { selected }\end{array}$ \\
\hline Total & & 77035 & 398 & \\
\hline
\end{tabular}

Source: (Researcher, 2018)

In this study, the researcher employed stratified sampling and simple random sampling techniques. Observation and questionnaires were used in data collection. Data collected was analyzed in tabulated form with the aid of simple percentages, tables, bar graphs and pie charts.

\section{A. Data Analysis}

The researcher distributed a total of 398 questionnaires to the respondents out of which 269 were correctly filled and returned back. This represented response rate of $67.6 \%$. According to Babbie (1990), a response rate of $60 \%$ is good, $70 \%$ very good and $50 \%$ adequate for analysis and reporting from manual surveys. Thus the response rate was deemed sufficient for further analysis of the research objectives.

\section{FINDINGS AND DISCUSSIONS}

When respondents were asked how much they earn from tea farming,majority of them indicated that $14.5 \%$ earned below 500, 22.7\% earned Ksh501-1000, 20.8\% earned Ksh
1001-1500, 27.5\% earned Ksh 1500-2000, 7.4\% earned Ksh2001-2500, 5.9\% earned Ksh2501-3000 while only 1.1\% earned above Ksh3000 per month from tea farming in Kisii County. This implies that there has been an increase in respondents who have been earning increased income along income categories. Thus the respondents were well versed with the topic under study on financial services access. However, it was noted that those earning ksh.1500-2000 do not depend on their tea farms alone but also pick tea leaves from hired land.

\section{A. Factor Analysis on Physical proximity}

Principal component analysis extraction method with varimax rotation method was used where validity was assessed by examining the factor loadings to see if the items in the scale loaded highly on the construct. Table 2 presents the results of the analysis for the number of items that had significant loading on each component factor.

Table 2: Rotated Component Matrix for Measures of Physical proximity

\begin{tabular}{l} 
Physical proximity items Component \\
\hline \\
Infrastructural \\
development enables tea \\
farmers in kisii county to \\
easily access financial \\
services for their \\
economic empowerment \\
\multicolumn{2}{c}{.728 } \\
Distance affects financial \\
accessibility by small \\
scale tea farmers in kisii .665 \\
county and their economic \\
empowerment
\end{tabular}


Awareness of financial accessibility enhances economic empowerment among small scale tea farmers in kisii county

ICT facilitates financial accessibility for tea farmers economic empowerment in kisii county

Mobile phones facilitate financial access for tea farmers in kisii county for their economic empowerment

Banking location in rural area enables access to financial services for tea farmers economic empowerment

Extraction Method: Principal Component Analysis.

Rotation Method: Varimax with Kaiser Normalization.

\section{Source: (Researcher, 2018)}

The results on Table 2 show that that the factor loadings of physical proximity items range from 0.511 to 0.833 . Except one item "Road networks hinder farmer's access to financial services for their economic empowerment" which did not meet loading cut off of 0.4 , the other six items met the loadings cut-off of 0.4 and were thus retained for analysis. A maximum of three factors were obtained, because the three factors had Eigen values which were greater than 1 and their extraction sums of squared loadings were greater than 1 . Factor 1 had the highest extraction sums of squared loadings of 1.284 , which represents 18.346 percent of variation. Factor 3 had the lowest extraction sums of squared loadings of 1.033 representing 14.762 percent of variance. The extraction sums of squared loadings of other factors were between the range of 1.284 and 0.770 . The contributing power of these other factors to the explanation of the variance in the variables was significantly considered.

\section{SUMMARY, CONCLUSIONS AND RECOMMENDATIONS}

\section{A. Introduction}

This chapter summarizes the research findings regarding the research objectives and hypotheses. The study sought to identify influence of physical proximity and awareness of access to financial services on economic empowerment among tea farmers in Kisii County. The research findings indicate that respondents were in disagreement that infrastructural development enables tea farmers to easily access financial services. Majority of the respondents held the opinion that distance affects financial accessibility among small scale tea farmers while awareness of financial accessibility was found to enhance economic empowerment among small scale tea farmers. In addition, respondents were in disagreement that ICT do not really facilitate financial accessibility among tea farmers economic empowerment in Kisii County.

Moreover, a larger majority of the respondents agreed that mobile phones facilitate financial access among tea farmers with disagreement that banking location in rural area enables access to financial services among tea farmers in Kisii County. There exist statistically significant, positive relationships between physical proximity and awareness of access to financial services and economic empowerment among tea farmers in Kisii County, according to the coefficient results of the individual regression model. Moreover there exists a weak, positive significant correlation between physical proximity and awareness of access to financial services and economic empowerment among tea farmers. 


\section{Physical Proximity and Awareness of Financial Service Access Strategy on Farmers Economic Empowerment in Kenya: A Case of Small Scale Agricultural Tea Farmers in Kisii County}

\section{CONCLUSION}

It can be concluded that influence of physical proximity and awareness of access to financial services has significant influence on economic empowerment among tea farmers. The results reveal that there exists a positive statistically significant relationship between influence of physical proximity and awareness of access to financial services and economic empowerment among tea farmers. Conclusions can be made that there is inadequate infrastructure development in the rural areas thus affecting financial accessibility among tea farmers in Kisii County. Moreover, distance and location of financial services providers inconvenience tea farmers in terms of timely accessibility of financial services thus affecting financial accessibility among small scale tea farmers. It can be concluded that although financial services has adopted technology in service delivery to enhance financial inclusion, the same has not really achieved the desired results in terms of enhancing the financial accessibility among tea farmers in Kisii County. However, it can be concluded that mobile banking has enhanced financial services accessibility in Kisii County, thus ensuring financial inclusion among tea farmers in Kisii County.

\section{RECOMMENDATIONS FOR POLICY}

Based on the research findings and conclusions, the following recommendations were made; It was recommended that the county and national government should ensure infrastructural development such as the road network to enables tea farmers to easily access financial services with ease thus enhancing farmers' economic welfare. Financial institutions such as SACCOs which are majorly preferred by tea farmers according to the research findings should ensure adoption of reliable technology which will be able to enhance financial inclusivity among tea farmers. Through use of ICT, financial institutions will be able to provide financial services to tea farmers hence enhancing paperless and branchless banking services. This will ensure even those in rural areas get access to financial services through the financial institutions ICT online platform. It was recommended that through collaboration between KTDA and financial institutions, tea farmers should regularly organize workshops trainings on financial literacy to create awareness on financial management and opportunities on their economic empowerment.

\section{CONTRIBUTION OF STUdY TO KNOWLEDGE}

The study shed light on how financial resources help rural communities function, how their relationships develop, how individual esteem is increased, their interdependence grows, and how this is facilitated in part by the infrastructure, location, ICT and awareness.. In this way, the study makes a significant contribution to our understanding of rural communities in developing economies, thereby allowing the relationship between financial service access strategies and economic empowerment among small scale tea farmers to be made clearer. In this way, the contribution is both academic in addition to the literature on county development, rural finance, standard of living issues, informal and formal financial functioning, and to practice - in the application of the findings to policy development, specifically in the financial sector.

However, the role of financial access strategies among small scale tea farmers on economic empowerment has not been studied in any systematic way. This study fills the gap by examining the main criteria of standard of living at the individual, household and enterprise levels which are not explicit in other studies. The gap was filled in the sense that the study engaged the literature in identifying the limitations of previous studies. Methodologically, the study began by considering the range of other researchers' methods, which include research strategies suitable for the study, and also identified users of these methods and the reasons for their choices. This process led to the choice of qualitative methods for the study through an organized system of data collection.

This study also contributes to knowledge by applying the financial deepening, inclusive information asymmetry theories to the research objective, so as to discover the contribution of financial accessibility strategies to small scale tea farmers' standard of living and its implication on farmer's economic empowerment. The uniqueness of this study is the application of financial service accessibility strategies in Kisii County with concentration on small scale tea farmer's economic empowerment. This not only enables us to understand more fully how financial access benefits flow from providers in Kisii county but, allows a more general statement of the effect of rural finance provision to the improvement of tea farmers.

\section{RECOMMENDATIONS FOR FURTHER RESEARCH}

The study employed a case study approach of Kisii County; it is recommended that this study be carried on a broader scale in Kenya. Yin (2003) asserts that a single case study findings cannot be generalized in compared to multiple case study. In determination of measurable indicators under each variable of the study qualitative research was used The study employed a case study approach of Kisii County; it is recommended that this study be carried on a broader scale in Kenya. The study recommends further research to test and validate the research findings using a quantitative approach.

\section{REFERENCES}

[1] Adams, S. (2010). Impact of microfinance on maize farmers in Nkoranza (Brong Ahafo Region of Ghana). Journal of Management Research, 2 (2), 3-7.

[2] Agostino, M. (2008). Effects of screening and monitoring on credit rationing of SMEs. Economic notes. 37(2-2008), 155-179. Banca Monte dei Paschi di Siena SpA. Oxford: Blackwell Publishing Ltd.

[3] Baloyi, J. K. (2010). An analysis of constraints facing smallholder farmers in Agrifarm value chain: A case study of farmers in the limpopo province. Pretoria: University of Pretoria. Banks in Kenya, University of Nairobi.

[4] Bazibu, M.(2005). Information Asymmetry and Borrowers' Performance on Loans in Commercial Banks. Unpublished MBA research dissertation. Kampala: Makerere University. 
[5] Burges and Pande (2005). Do Rural Banks Matter? Evidence from the Indian Social Banking Experiment. American Economic Review. Pp. 780-788.

[6] Duncombe, R. and R. Boateng. (2009). Mobile phones and financial services in developing countries: A review of concepts, methods, issues, evidence and future research directions. Third World Quarterly, Vol. 30(7):1235-1258.Egerton University Press.

[7] Eriksson, K., Kerem, K. \& Nilsson, D. (2008). The adoption of commercial innovations in the former Central and Eastern European markets: The case of internet banking in Estonia. International Journal of Bank Marketing, 26 (3), 154-169.

[8] Haniffa, R. \& Hudaib, M. (2006). Governance Structure and Firm Growth of Malaysian Listed Companies, Journal of Business, Finance and Accounting, Vol.33. No.7. pp.1034-1052

[9] Kaynak, E. \& Harcar, T. D. (2005). American consumers' attitudes towards commercial banks: A comparison of local and national bank customers by use of geodemographic segmentation. International Journal of Bank Marketing, 23 (1), 73-89.

[10] KTDA.(2017). Kenya TEA Development Authority region 6, report.

[11] Kyale, M. S. (2013). Impact of microfinance institutions on growth and development of small

[12] Laforet, S. \& Li, X. (2005). Consumers' attitudes towards online and mobile banking in China. Interna 196

[13] Nam, S. \& Ellinger, P. N. (2008). Branch Expansion of Commercial Banks in Rural America. AmericanAgricultural Economics Association Annual Meeting 2008, Orlando, FL, July 27-July 29. University of Illinois at UrbanaChampaign.

[14] Neven D., Odera M. M., Reardon T. and Wang H. (2009). "Kenyan Supermarkets, Emerging Middle- Class Horticultural Farmers, and Employment Impacts on the Rural Poor", World Development, Vol. 37, 1802-1811.

[15] Othieno, E. A. (2010). Bank lending, information on asymmetry, credit. Kampala: MakerereUniversity.Google Scholar

[16] Porter, R. C. (1966). "The Promotion of the Banking Habit and Economic Development." Journal of Development Studies 2(4): 346-366.

[17] Saunders, S. G., Bendixen, M. \& Abratt, R. (2007). Banking patronage motives of the urban informal poor. Journal of Services Marketing, $21(1), 52-63$.

[18] Tobbin, P. (2012). Towards a model of adoption in mobile banking by the unbanked: a qualitative study.info, 14 (5), 74-88.

[19] Tustin, D. H. (2010). An impact assessment of a prototype financial literacy flagship programme in a rural South African setting. African Journal of Business Management, 4 (9), 1894-1902.

[20] Zhao, A. L., Hanmer-Lloyd, S., Ward, P. \& Goode, M. M. (2008). Perceived risk and Chinese consumers' internet banking services adoption. International Journal of Bank Marketing, 26 (7), 505-525 